\title{
HISTORY OF THE WORKING CLASSES IN FRANCE:
}

RENAISSANCE AND MODERN PERIOD.

M. LeVASSEUR's second volume ${ }^{1}$ is, if possible, even more enjoyable and suggestive than the first. Several leading economists called his work, when it appeared in its first edition, a model of accuracy. The present edition deserves this praise even more absolutely. The material on which $M$. Levasseur bases his presentation of the vicissitudes of industry and the laboring classes is in every respect excellent and amply justifies his views. If the reviewer, while examining the wealth of illustration contained in the first volume, felt conpelled to keep in abeyance any dissenting opinion of his, he feels still more so as he penetrates into the contents of the second volt:me, with its vast storehouse of information and the careful investigation on which it rests. The following pages will be, as before, an attempt to give the general reader and the student an idea of the interesting contents of the volume. M. Levasseur in his work goes as much as possible into detail, and repeats himself frequently in an endeavor to be perfectly clear and simple. Our review is but a rapid summary of the most prominent features of this important production, and has sufficiently served its purpose if it induces students to examine the volume for themselves.

When the French crossed the Alps in I494, M. Levasseur tells us, they found in Italy manners more elegant than theirs, a refinement of civilization unknown to the North. Italy was to them like the discovery of a new world. It was then the richest country in Europe. Lombardy resembled a garden; in the cities large numbers of the inhabitants were busy with industry and trade. Silk goods, gold and silver brocade, glass, fayence, perfumery, and other luxuries were fabricated there. The satins and velvets of Venice and Genoa, the fayence of Bologna and of Urbino, the jewelry of Florence, Rome, and Venice, the glassblowers of Murano, were all renowned. Italy had become the international market of two worlds, and the general prosperity and the rivalry between

${ }^{1}$ E. LeVASSEUR, Histoire des classes ouvrières et de l'industrie en France avant I789. Tome second. Deuxième édition. Paris: Rousseau, I90I. 8vo, pp. $98 \delta$. 
the courts had created habits of elegance and a search for the beautiful. The French were dazzled at the sight, and became the imitators of the people whom they had set out to conquer. Charles VIII. brought back with him wagonloads of tapestry, books, pictures, and statuary which he had taken, besides artisans and artists whom he had induced to come to France and work for him, and some of whom actually remained in France. The expeditions of Louis XII. and of Francis I. multiplied these relations to Italy. The nobility came to desire a life different from that which they had hitherto enjoyed. Instead of living as before penned up in their castles and donjons, they now wished for gardens with statuary, fountains, and merry gatherings. The royal court drew the lords by its brilliancy, and set the example in display and festivities. Luxury made rapid progress. Between the prison-like Plessis-lès-Tours of Louis XI., with its moats and pitfalls, and the sumptuous Field of Gold and the court at Blois, there was a revolution in the habits and ideas of the people. In order to keep this splendor going and satisfy the new cravings, the Valois did not spare money. The expenses of the king were 45,000 livres tournois in 1480 ; in 1556 they were I 44,000 . And a Venetian ambassador observed that now every workman, every mariner, wanted to have meat on his table like the rich. "Every laborer wants to make his son a gentleman," said Bernard Palissy. Laws were enacted against luxury in dress, but the commoner who earned plenty of money did not hesitate to spend it. Laws could not prevent him. The court set the example in patronizing the arts and the artistic industries. New kinds of wood came into use-for furniture and utensils - oak, walnut, and ebony. Silverware was rare except among the richest; the ordinary burgher used copper or tin. The wonderful discovery of Bernard Palissy raised French fayence to the rank of art. Jewelers, enamelers, and glassblowers produced work of high excellence. Printing-presses, binderies, tapestry, all the noble crafts flourished, largely through the interest taken in them by royalty and those who wished to imitate the munificence of the court. The price of books had decreased astonishingly since the fifteenth century; a Tacitus cost 6 sons, a Virgil 3. A bookseller did not hesitate to venture 60,000 francs on an edition of Galienus, nor 186,000 on a Bible glossary in seven volumes. The royal government encouraged commerce, too; fairs were established and protected. Something was done 
for sanitation. In the cities every houseowner was enjoined to sweep before his own door; it was left to the magistrates to supervise the general cleanliness, and a tax for the purpose was levied on every property holder; but the age, if fond of display, was not very neat, and the general condition remained much the same as before. Still population had increased, and many cities were rebuilt and enlarged. Paris had changed since the time when its houses lay in ruins. In I448 the kings had complained of the loneliness of the capital; in 1558 they were frightened at its growth and forbade the building of new houses in the suburbs. The population was almost 400,000. Intercourse between Italy, Germany, Flanders, and France was reviving; Lyons was the great meeting-place for Italian and French trade, and had a fair share of Flemish and Spanish trade besides. The commerce on the Seine was especially active beyond Rouen and on the Garonne from Bordeaux; on the Mediterranean Marseilles and other cities traded with the Levant, Egypt, and the coast of Barbary. The alliance between Francis I. and the sultan opened the east to French trade; French merchants had shops in Alexandria, Cairo, Beirut, and Tripolis; and the political and economic influence of France was at its height in all the possessions of the Sublime Porte. The commerce in the interior prospered too. The sixteenth century was the most brilliant epoch of the fairs at Lyons, and Paris was the storehouse of France. The money changers, who had had less luck since letters of exchange (in imitation of Italian methods) and the suppression of seignorial coinage, in 1555 saw their profession raised to the dignity of a royal office. There were twenty-four exchanges established in Paris, twelve in Rouen, Toulouse, and Lyons, six for places of minor importance, and two for the smallest towns. In reality the king intended thus to establish a financial resource for his own benefit. Banks, too, came into use in France in imitation of Italy; the bankers being at first submitted to the following severe rules: each must be a born or naturalized Frenchman, obtain royal sanction, and deposit I5,000 livres with the treasury. In I54.3 Francis I. was persuaded to establish a bank at Lyons, where commerce made it imperative. At this time, too, commercial tribunals were formed which passed upon mercantile causes. A judge and four consuls chosen by merchants, and merchants themselves, were to judge without fees and on the spot differences arising from commercial agreements, and their judgment was final in mat- 
ters not exceeding 500 livres. The municipal magistrates interfered with the working of the courts largely from jealousy, and the king had finally to take the matter in hand and confirm their right of jurisdiction. Some attempts at protection of native industry against foreign competition mark the period. Duty was levied on Flemish and Spanish imports. In I540 importation of Italian goods could take place only through Lyons, and of Spanish goods only through Narbonne and Bayonne (showing that some of the latter came by sea). But such signs of prohibitive measures were as yet rare. The kings generally let the merchants buy and sell as suited them. Sully looked upon this as a natural right, and demanded it for agriculture no less than for industry. Henry IV. during a famine forbade export of cereals, but at the same time explained that "experience teaches us that freedom of exchange between the subjects of one kingdom and those of another is one of the principal means of making them happy, rich, and opulent." The ideas about this matter were generally so confused that a speculator was not afraid of asking Charles IX. for the sole management of the foreign trade, offering in return the relief of certain domains. The royal council saw no objection to this impossible project, and it might have been carried out had not the protest of the merchants, when asked their opinion, prevented it. "France," said the Venetian ambassador, "produces all things necessary for the subsistence of its inhabitants." In fact, cereals, wine, meat, and fish were plentiful. Wood was dear because the king as proprietor of the greater number of forests took advantage of his monopoly. The soil gave flax, hemp, saffron, and madder. The salt works and the iron mines were numerous and rich. Wool alone yielded a considerable income. Industry put all these resources to use, and commerce supplied the wants and effected the exchange. The commerce with Venice diminished after France began to manufacture silk. Spices came from Lisbon. Germany and England alone sent a thousand vessels every year to the French ports. Under Henry II. two-sixths of all imports came from Italy and the Levant, one-sixth from Spain, another sixth from Germany; the Netherlands, England, and Portugal furnished the rest. The Spaniards and Portuguese exported silver and gold, and gained $\mathrm{I} 5$ and 20 per cent. from the trade, notwithstanding the stern prohibition of export of the precious metals issued by the Spanish kings. In exchange France gave grain, wines, dried fruit, woven goods, salt, and blue and yellow dyes. 
No trade offered her such advantages as the Spanish, and to Spain her artisans flocked, sure to find employment among the rich but indolent possessors of America. France thus enjoyed a hundred years of continued prosperity from 1498 till the beginning of the religious wars. Then the country was ravaged, the population diminished, manufactures and commerce suffered a setback, and a large percentage of artisans and laborers, previously self-supporting, came to exist on alms.

After these introductory remarks M. Levasseur proceeds to discuss the monetary revolution during the sixteenth century, which, at first unperceived during the first half of the century, was only too evident during the second half, and profoundly modified industrial and commercial conditions. After the Hundred Years' War prices went far below what they had been for centuries, and remained so until the reign of Francis I. Gold and silver were scarce; the value of land rose, however, largely because of the increase in population, but in spite of this grain remained cheaper than it was a hundred years before. America had been discovered, and the influx of precious metals began almost at once. From ${ }_{5} 520$ to ${ }_{5} 544$ the American mines produced something like 90,000 kilograms of silver per year (more than 198,350 pounds), much more than Europe had hitherto produced. The equilibrium of values was accordingly destroyed, the precious metals lost, while other matter, for example land, rose (as the list of M. d'Avenel shows) to twice its former value and grain became somewhat more expensive. After the mines of Potosi were discovered the output rose to 300,000 kilograms per year, and matters grew worse. The nobility, whose income consisted in fixed rents, was greatly afflicted, while the commercial classes gained. Many burghers bought land, and since nobility depended on possession of noble estate, they became in their turn founders of nobility. Prices of merchandise rose as well; what had formerly cost 2 francs.now costing at least Io. The purchasers began to accuse the sellers of speculating. According to M. Levasseur, the purchasing power of money, at least as concerns the breadstuffs, from 1500 to 1589 is best shown in the prices fetched in the central corn market in Paris, where the average price for the first twentyfive years appeared to be 2 francs per bushel, but rose steadily until in 1600 it was as much as 10 francs. The change in price was not due to any scarcity in the supply of grain, but to the increasing cheapness of money. The decreasing value of silver given in 
periods of twenty years is illustrated by an accompanying table ( $\mathrm{p}$. 63). The tables and estimates are in fact a very important part of M. Levasseur's book. The author warns us, however, against assuming that because the purchasing power of silver was apparently very much the same then as now (I.4:I for Paris and I:I for the rest of France), one received as much for one's money then as now. Grain then was relatively much more expensive, yet even so purchasers had been able to buy three times as much in $145 \mathrm{I}$ 1500 as they were in $1576-1600$. This reduction of value was sufficient to upset a great many fortunes, and the change in coinage which diminished by half the amount of silver in a pound tournois aggravated the situation. At the end of the fifteenth century II livres tournois were equal to I mark fine silver, I pound containing as much silver as is in $4.7 \mathrm{I}$ francs nowadays. In 1602 one mark was made to contain 20 pounds, 5 sous, and 4 denars, the pound being equal to only 2.18 francs. If multiplied by the purchasing power which M. d'Avenel has hypothetically assigned to silver (p. 64), the pound for the year I497 is worth 28.26 francs, and for the year 1602 only 5.45 francs; which means that one could buy five times less of merchandise with I pound silver (tournois) in 1600 than in 1500 . The value of silver as compared with gold in 1497 was II.8:I, and II.9:I in I602. The principal gold coin was the gold crown (with the image of the sun over the crown). It was counted equal to 36 sous in 1497 , and to 40 sous in 1519. As silver money became depreciated, more silver coins were required to equal the gold coin. The kings tried to interfere by demanding in 1574 that the crown (écr de soleil) be counted at 58 sous, and in 1575 at 60 sous. But the command was unheeded, and the crown was pushed to 68 sous. It was finally decided to adopt the gold coin as standard, the crown by edict of 1577 being counted equal to 3 pounds silver. Objections to this radical change caused Henry IV. in 1602 to return to the old method, counting the crown equal to 3 pounds 5 sous, or ir.6:I. The consequences were not unimportant. Land cost five times as much in $I 600$ as a hundred years before, but the pound of silver had only one-half of its former value; besides, silver as purchasing metal was reduced from 6 to $2 \frac{1}{2}$. Those who in 1500 had been able to buy to the value of what now might be 1,000 francs had at this time with the same income only 200 francs to dispose of, and were accordingly tuined. The increase in salary noticeable at this time was nominal 
rather than real. A day laborer who in $150 \mathrm{-}-25$ received, as it were, 60 centimes, not counting board, received in $1576-1600$ eighteen centimes more, but the purchasing value of his wages was lessened by more than one-third. M. d'Avenel calculates that, while the wages of a day laborer for 250 working days equaled, toward the end of the fifteenth century, the produce of 32 hectares, or 79 acres, and while at the beginning of the sixteenth century the wages were still equal to 46 acres, yet in 1600 they represented only 23 acres. Hence the situation of the day laborer was anything but encouraging. Or, to take another example: in $145^{\mathrm{I}-75}$ a mechanic could buy with his daily wages more than 18 liters of wheat or 26 of rye; in I5OI-25 he could still buy more than 14 or 18 liters of one or the other kind; but in $1576-1600$ he could buy only 4 liters of wheat or 5 liters of rye. In the sixteenth century the breadstuffs seem to have been the commodities which had increased most in price, while human labor had increased least. M. Levasseur makes some comparisons between demands on life in the sixteenth century and now, and concludes that if life is more expensive now than it was, this is because of the assimilation of certain general wants by all classes, an assimilation which was unknown in the sixteenth century. Hence, although there was less money to go around in 1600 , it cost less to live than now, and the progressive dearness of living is shown by the increased cost in 1600 as compared with 1500 .

Increase in taxation was the ultimate result of the increase in offices following the new organization of government, the development of industry, and the depreciation of money. In 1497 the total revenue was $16,306,000$ francs; in 1535 the Venetian ambassador, who was always well informed, estimated the royal revenue at $28,750,000$ francs; and in 1563 he makes it out something like 69 million francs. Large cities, such as Paris, Rouen, etc., were free from a portion of the direct taxes, which fell with so much the more weight on the peasantry; but instead the cities were expected to make certain gratuitous gifts to the treasury-gifts which, whether large or small, the Valois expected to grow with the years. These gifts are supposed to have amounted to 455 million francs from the accession of Henry II. till the end of the sixteenth century. At the accession of Francis I. the taille amounted to nine million francs. In $\mathrm{I} 597$ it was 45 million. The restrictions of commerce in the form of tolls still existed. One hundred toll 
stations in 1567 interfered with the navigation of the Loire; ten years later they were supposed to have been reduced to only seven, but $M$. Levasseur thinks there were many more. The king by his ordinarres tried to make the waterways free, but it was beyond his power. An ordinance of I559 prescribed a space of at least eighteen feet to be left free, probably for the passage of boats making their way to the sea. A list of duties on foreign imports (pp. 84, 85) is very instructive, but too long to be reproduced here. A complete tariff was issued in I549 comprising wool, woods from the West Indies, leather, tallow, hemp, cotton, oil, wine, peddled goods, metals, woven goods, hides, furs, arms, and edibles, a duty of 4 per cent. being charged on the assessed value.

It has already been said that corporations did not exist in every town. The king, however, looked upon the guilds as an element of order, and hand in hand with the extension of royal authority went the authorization and extension of the guilds. It should be supposed that as royal power grew the less would be the need of using the guilds as a prop, and the less would be the desire to join the corporation on the part of the free artisans. But the opposite seemed to happen; the more industry developed, the more grasping were the privileged artisans, the more anxious the nonprivileged seemed to be to enter the combination, and the more hostile the guilds seemed to become to any effort on the part of outsiders to pursue their professions individually or form new associations. With the growth of monopoly the distance between master, companion, and apprentice became wider, and the completion of the masterpiece was made more difficult for those who could not buy themselves free from the test. Certain masters ceased to teach their apprentices, presumably in order to hold them longer in subjection. Young men of means bribed their masters to help them or to overlook their mistakes. The corporations grew more abusive as they grew more restrictive. Masters and companions complained of one another, the masters usually having the better of their inferiors, who were too dependent upon them for their living. Strikes were heard of among the bakers in Paris and the printers both in Paris and Lyons. Long controversies, the masters and workmen alternately appealing to king and parliament, grew out of such differences, which were never quite patched up and increased the hard feeling. Most noisy was the bakers' strike, where the workmen paraded the streets with sticks and swords, and 
threatened the masters and even those among themselves who dirl not participate in their actions or share in their hatred.

The exclusiveness of the guilds was not quite to the government's taste, however. It smacked too much of feudal rights and obstructed the kings' desire for uniform government. The kings on their side made the mistake, usual to arbitrary power, of creating offices for the supervision of the trade and granting letters of mastership within every corporation - a method which, if it worked well in a few cases, did ill in most others, since the desire for creating revenue for the exchequer was more potent than the desire to benefit industry. The kings' hostility toward the fraternities had a better reason, that the banquets and assemblies caused frequent disorders and expense to the poorer members. But for each fraternity suppressed two new ones sprang up. The society of peddlers was suppressed and remained so. In $158 \mathrm{I}$, under the supposedly worthless Henry III., the government aimed a definite blow at the old order and organized the trades anew by commanding (I) that all artisans within the kingdom have themselves enrolled in corporations; (2) that admission be made easier, so that none be left out owing to mere formalities; (3) that the corporations be placed more directly under the king's government, and associations within the guild be suppressed; (4) that an impost be laid on labor for the benefit of the royal government. One sees that the royal strongbox was not forgotten even in the profession of great concern for public prosperity. Other regulations limited the work on the masterpiece to a reasonable time (three months instead of a year). Every artisan enrolled had to swear allegiance to the king. By letters patent three masterships were established free of charge within each corporation, thus enabling poor artisans to become masters without great expense. The all-important fiscal question received due attention along with the liberal provisions.

With the accession of Henry IV. began a new era of paternal government. The religious wars had proved destructive to French industry, which had been in such a fair condition. The League had shown its spirit by pillaging the farms and despoiling the merchants. The cities had not suffered any less, even if protected by walls. Manufacture in some cases ceased to exist. As often happens in case of prolonged war, luxury had not ceased even if necessities were wanting; hence, where industry catered to the denands of the rich it had remained intact and even flourished. 
Thus silks and fine woolens and linen stuffs still commanded sales. Henry set himself resolutely to restore peace and prosperity both in agriculture and industry. Sully was most interested in restoring well-being to the humble husbandman, while Henry thought industry and commerce the most important sources of a nation's wealth. It would be too lengthy to repeat the author's discussion of the work of Henry IV. and his ministers. Suffice it to say that the king had the needs of the treasury in mind just as much as the welfare of the people. The ordinance of I597 repeats the commands of the edict of sixteen years before emphasizing the need of freedom in the narrow circle of economic life within the guilds. In I60I a commission of seventeen persons was appointed to suggest further what might be done for the advancement of the trades. The commission examined into the statutes of some of the corporations with a view to improving the products. Experiments began with a view to transplanting silk manufacture from the south to Paris, and the king strove to interest private capital in the attempt, but it failed. Other lines of industry, such as weaving of tapestry, were more successful. An attempt to set up looms for weaving of linen in competition with the Dutch was liberally supported by the royal exchequer, yet had no marked result. But the chief enterprise with which the name of Henry IV. is connected is his starting those royal manufactories which were the first attempt at industry on a large scale freed from the narrow supervision of the trades, and which came afterwards to be of such importance for French export and influence in European markets. The king's desire was to limit importation to a minimum, and by so doing draw gold and silver into the country, the precious metals alone being considered wealth. But he also wished to save the people from misery by preventing them from being idle. As Richelieu put it more brutally: The people is like a mule, it gets spoiled if left with nothing to do. The king found the corporations obstinately opposed to his plans for the creation of larger establishments. Letters patent gave certain entrepreneurs freedom from the supervision of the trades, but the guilds never ceased to clamor against such breach of their ancient rights. In many of these instances the king had furnished the capital or part of it, or had encouraged the formation of companies. In the Louvre the king gave the lower floors for shops and lodgings, and although the corporations remonstrated, the king was not to be moved; and the Louvre for almost 
two hundred years was the cradle of art and artisanship of the highest grade, a reputation which was bitterly envied by the guilds.

The prospect of royal pay and royal favor attracted foreigners, who again were forced to seek their customers largely outside of France and thus met foreign competition on its own field. ${ }^{\prime}$ Under Henry IV. royal establishments had but middling success, but later ages enjoyed the fruit of the attempt. French industry grew, without reaching, however, the height or prosperity of the Renaissance. The formation of companies for extending trade with the colonies, particularly with the New World, and treaties with foreign countries marked the judicious and far-seeing policy of Henry IV. Under Richelieu these projects were but little favored. Richelieu had too deep an interest in politics to pay full attention to economic matters. The Thirty Years' War without and the machinations of the nobility within naturally absorbed all his energy. Art had in him a generous patron, but the need of money and the subsequent taxation weighed heavily on the people. Yet he gave them at least just government and security. His regulations of industry had largely the object of counteracting fraud, and his chief undertakings were in regard to furthering communication by multiplying the roads and opening new avenues of commerce. Several rivers were made navigable, bridges and highways were reconstructed, and the postal service began to act regularly. A strong navy protected foreign trade, treaties were concluded, and the colonies were not altogether neglected; but bad luck seemed to pursue French enterprise in America, and only the French settlements in the Antilles gave hope of return in the future. The administration duing the minority of Louis XIV. failed in many ways to continue the good work begun and was more concerned about present revenue than building for the future. When Louis XIV. came to the throne, everything languished. While the names of Henry IV. and Richelieu are conspicuous in French economic history, that of Mazarin has really no place there at all.

Louis XIV., M. Levasseur says, had not only the good fortune of meeting men of excellence and ability, but also knew how to attach them to his service. He owed his greatness partly to the circumstances which preceded his reign, partly to himself, for never has a prince known how to govern with more majesty. And France was ready to submit to an absolute government. She had lost in political liberty, but gained in unity. The man to bring 
about this unity, for the benefit of the nation, as he thought, was Colbert. Absolutism had no more devoted servant-a minister at once ambitious and diligent, passionately imbued with a desire for order, brooking no resistance. He was an organizer of monarchy in the works of peace, and for twenty-two years he brought his vigilance and his reforming spirit to bear upon the remotest parts of civil administration. If he committed errors, he rendered at the same time so considerable services to the state that it is easy to pardon his mistakes. His first and greatest merit is to have created order in the finances by establishing regularity in the imposts. This, while it eased the burden, more than doubled the receipts ( 32 million francs instead of $\mathrm{I} 3$ million as before). In I66I the revenue rose to $\mathrm{I} 37$ million francs, and yearly budgets were made out on which income and expenditure could be easily seen. These were presented to the king for inspection, and were approved by him - a simple remedy, it seems, but where is the simple remedy which has not once upon a time been a great discovery? The clearing away of old abuses left a freer path for justice and in its wake for the peaceful arts. The provinces had been badly administered, the representatives of the king's civil power, the intendants, having been subject to the military governors. By liberating the civil power and placing it directly under the king, the intendants became masters of their provinces in all matters concerning police and finance. A constant correspondence kept them informed of the wishes of the king, and their opinion was asked in all affairs which concerned their province. How deplorable in one way was the loss of provincial and municipal liberty! Yet in another way the people gained by having one rather than many masters. Colbert's plans were indicated in an early letter to Mazarin where he pointed out

that it was necessary to re-establish or create anew all the industries, even those which depended upon luxury for their maintenance; that it was necessary to establish a system of protective tariffs, to organize producers and trades people into corporations, to alleviate the fiscal burdens which had proved too heavy for the people, to restore a merchant fleet for the transport of French products, to develop the colonies and attach them commercially to the mother-country, to overcome the difficulties in the way of direct connection between France and India, and to develop a navy to protect the merchant fleet.

To make France independent of foreign produce, keep everybody busy, prevent idleness, utilize native products, keep capital within 
the kingdom, and draw money from abroad - very much the same ideal as Henry IV. had tried to realize - and by means of this wealth pay the taxes, which again were necessary for the support of a strong government - these were the lines along which he proposed to act. A thousand pities that the ambition of Louis XIV. ran so entirely at cross-purposes with his! The system of Colbert was based on the all-powerful authority of an absolute monarch, and his system as the weaker part became quickly subservient to and absorbed in the destructive policy of the monarch. To organize the corporations was Colbert's first care - he hoped thus to prevent fraud more easily. To do this in such a way as to further the professions, he revived the old Council of Commerce which Henry IV. had called into existence, and sent commissioners to the provinces to consult manufacturers and merchants and discuss the matter with the corporations themselves. The encouragement his plans received Colbert took for an expression of unanimous consent; too often, however, the desire to please the almighty minister had got the better of truth, and the opinion of the workmen seems not to have been heard at all. The protests forwarded to him he took for an expression of an obstreperous spirit rather than sound advice. In 1669 the famous four ordinances saw the light, which should regulate the manufacture of woolen goods particularly, and in which the obsolete rules for the length and width of a piece, with other minute rules as to salvage, number of threads in the warp, the quality of material to be used, and the mode of manufacture, were revived and extended to comprise all instead of a few kinds of goods. The intention of Colbert was to re-establish the old high reputation of French goods - a generous idea in itself, but ill advised in its present expression, since the manufacturer was sadly handicapped as to the choice and working of his material, and the purchaser equally limited as to price and variety. In other ordinances the minister went farther into detail, making them rather instructive reading for the student of today. Every maker and master was to have a copy in his shop and bind himself by signing his name to obey them implicitly. Besicles, in order to verify the maker each product was to have its mark, the weaver attaching his, the dyer his, the owner of the factory his, and the royal inspector his, with the arms and name of the city on one side, on the other the image of the king with this (to us almost ironical) inscription: "Louis XIV., restorer of French manu- 
factures." The penalty for neglect of rules was severe: heavy fines, confiscation, imprisonment, and, if repeated, exhibition of both manufacturer and goods at the pillory - a sad instance of what despotic power may lead to, M. Levasseur reflects.

Colbert was very active, too, in aiding the industries already flourishing and inculcating a more enterprising spirit into the towns, where idleness seemed to him the chief obstacle to the accumulation of riches. He was also the supporter of royal manufactories or such private enterprises as gained their success by selling their products to the state at a set price. Colbert gave freely to all whenever he thought their existence or example a benefit to the nation, and paid good prices when he thought it important to encourage them. He urged cities and provinces to do as the king did, since large capital was often needed to set on foot anything new. The king even honored some of these establishments by his royal visit and ennobled some of the directors. The royal manufactories were authorized to bear the royal arms over their entrances. The employees enjoyed certain immunities, and above all the special protection of the king. The famous factory of Gobelins, which had been abandoned after the death of Henry IV., but which Colbert had revived, was one of these. The best artists made the drawings not only for tapestry, but for furniture, statuary, and mosaic for the decoration of the royal palaces, and orders were executed for outsiders as well. Lace manufactories were also under royal protection; factories for stockings, worsted and silk, cloth, linen, foundries and forges, soap works, shipbuilding establishments, some of which were new industries, were introduced and subsidized by the government for the help they might give to home enterprise. The title "royal manufactory," or the privilege conferred by letters patent to start a new enterprise, was a palladium which sheltered the entrepreneur against suits in court and seizure. Such a factory, if in straits, needed only to appeal to the king, who helped it with his money and his favors. In order to be so assisted it was necessary to have something new to present for consideration an invention or some fresh project for the benefit of home industry. The manufacturer could henceforth conduct his operations free from the jealous supervision and chicane of the guilds; he could have larger workrooms, more workmen, put more capital into his enterprise, and turn out more work; in fact, attempt industry on a larger scale than if he had been a member of the guild. These privileges 
were often claimed for enterprises which proved of no particular worth, hence abuse and revolt on the part of the corporations, which were wide-awake critics, watching for the smallest misfortune befalling their rivals. Colbert drew many foreigners to France, but showed himself fiercely jealous of any attempt of foreigners to draw French industry. His monopolies necessarily thwarted the small industry, and the ill-feeling on the part of the workers in the guild was probably well justified. But Colbert looked upon the gain for France to come from the larger industries as more than paying for the loss in other quarters. He kept up a constant correspondence with the directors of the various establishments and did whatever seemed feasible to stimulate their activity. But with all his ardor his system had a grave fault: the will of a single man, however sincere and powerful in its utterance, could not replace the free action and initiation of a nation, and many of his creations perished as soon as he took away his protecting hand. M. Levasseur follows up his discussion of the policy of Colbert with a review of the industries as pursued in the different provinces in the north, south, west, center, and east of France. Whatever the faults of Colbert's system, France appears from this review a beehive as truly as is Belgium today. For some of the provinces of the south an estimate of export and import is reprinted which gives an exceedingly interesting idea of the activity of this portion of the kingdom. Evidently the merry south was not a lazy south.

It was feared that when Colbert died manufacture in France had seen its best days. And, in fact, Colbert's successors in royal favor cared nothing for industry, but nevertheless continued to establish new factories so as to find occupations and sinecures for their friends. They established them with this difference, however, that instead of making these enterprises state establishments, private individuals were given letters patent and left to themselves. The trade regulations were maintained, and where they were found wanting in strictness and explicitness the intendants supplemented them according to their lights. The Council of Commerce, which had not proved of any particular use during Colbert's administration, was supplemented by chambers of commerce in the principal cities. The presumptuousness or ignorance of the ministers that followed Colbert is partly to be blamed for the revocation of the Edict of Nantes, which was a worthy ending of the unpardonable misgovernment of the last years of Louis XIV.'s reign. The 
emigration is set at from 100,000 to 600,000 for the period $1660-75$ only, but the exodus lasted till the middle of the eighteenth century, and the grand total is probably not exaggerated. During the last wars which determined the political position of France, manufacture had a further setback, and bad harvests created great misery. The citics were again flooded with paupers, finances were in their habitual disorder, and a national debt of 6 millards 193 million francs weighed on the people - the beginning of the end. To fill the lacuna new offices were created - the standard remedy, as futile as it was foolish. As a courtier said to Louis XIV.: "As often as it pleases your Majesty to create an office, God straightway creates a fool ready to buy it." M. Levasseur dwells at some length upon these offices, their astonishing number, and their superficial relation to the tracles for whose guidance and supervision they were established. Sometimes the corporations escaped the doubtful benefit of royal appointment by paying a lump sum into the treasury and choosing the officer among their own. The sums the treasury received on such occasions approach the boodle of modern times. One city bought itself free for 70,000 francs, another for twice as much, and the corporations ran heavily into debt in order to produce so much money. M. Levasseur gives a long list of offices created during twenty-five years, with the sums which the sales brought. The kings of France were notorious for their bad management, otherwise such sums ought to have permanently relieved the treasury and with the taxes sufficed for all reasonable needs. In fact, M. Levasseur shows that in 1755 in Paris alone there were $2,46 \mathrm{I}$ titulary offices, and in I700 in the generality of Orleans there were no less than 7,747 royal and seignorial officials, as compared with only 6,182 merchants, wholesale and retail. The result of such misrule could not but become manifest in the increasing incapacity of a long-suffering population to meet the demands. No wonder that the French people, informed by historical research of the true nature of the past, has proved unwilling to return to monarchy.

Meanwhile the inner life of the corporations remained very much the same. The apprentice was accused of loafing whenever out of the master's sight. The absence of any definite agreement between master and workman left the condition of the latter rather precarious. The workman might often find himself without food or job, and the master abandoned at short notice by his workmen might equally often find it impossible to fulfil his obligations. The 
statutes sought to counteract this by demanding a week or less during which each party might look around. But the statutes, of course, had not the force of law, and the mutual hostility between masters and companions paralyzed what compelling power the statutes might have had. Better situated and probably more con* tented was the workman in the large manufactories where labor was of a more divided nature. Here, if the wages were smaller and the discipline perhaps even stricter, the opportunity for advancement was greater. The privileges of the trade inculcated greater self-respect in the individual, which was of no small importance at a time when the worker in the guild complained of avarice, cruelty, and intolerable pricle on the part of the masters. In the larger establishment there was a more secure future before the diligent artisan, and petty tyranny had no such chance as in the small workshop. The disorders caused by strikes and revolts on the part of the trade unions continued; they were a part almost of everyday life; and although the unions were prohibited again and again as a disturbing element, they were too helpful to the workmen themselves as a means of power and control to be ever really abandoned. United resistance gave them a chance in their struggle with the many in authority above them, whereas isolation would have meant their total subjection.

Wages and prices receive M. Levasseur's close attention. $\mathrm{He}$ deplores that it is well-nigh impossible to reach definite results with the material at hand. An examination of his lists of wages for the principal trades from 1601 to 1725 and from 1625 to 1750 seems to show wages, when not stable, to be declining rather than otherwise. The debasement of money by one-half may have had something to do with this. The price of land rose toward the middle of the seventeenth century, and declined afterward. Grain rose in the larger portion of France. Hence the laborer was better off than at the time of Henry IV.; but, seting aside the peculiar conditions caused by the monetary revolution, M. d'Avenel, to whose calculations of prices and consumption M. Levasseur constantly refers, believes there has been no period when the laborer procured so little food for the amount he had to spend as in the seventeenth century a fact which speaks curiously for the condition of the laboring classes during this most glorious period of French history. Strange to say, the wages of the laborer increased as the glory of the great king diminished. M. Levasseur wonders whether the revocation of 
the Edict of Nantes had anything to do with this. We can only refer the reader to these interesting pages for more complete information (pp. $394 \mathrm{ff}$.). On the whole, it seems as if expenses had increased in every line for the laboring classes, with no really adequate return from either agriculture, industry, or commerce, the egotistic policy of the government having closed every avenue except those from which a steady stream of coin flowed into that vessel of the Danaides, the royal treasury. The corporations, which the government had exerted itself to make permanent, were bowed down under a growing debt and had scarcely the funds with which to pay the interest - a debt which the government itself had brought upon them.

M. Levasseur gives us a short résumé of the transactions of Law and his irredeemable currency. He thinks that the identification of Law's bank with the government as a royal bank was the original cause of its downfall, largely because of the reckless waste and mad speculation to which such an undertaking would necessarily become subject. The government had never hesitated to rob its subjects by depreciating the currency, and its countenancing the issue of paper money without any adequate amount of gold or silver to back it showed the same sublime foolishness and blind faith in its prerogatives. Law did one thing for which he may sincerely be praised; because he expected to enrich the exchequer in other ways, he could afford to release industry from its bondage, lower duties, and open the frontier to foreign products, as well as abolish hindrances to commerce in the interior. But the dream of wholesale prosperity, miraculously acquired, was short. After three years, during which France was in a mad whirl, the bank suspended its payments, and a stupendous wave of bankruptcy swept away the fortunes of both laymen and ecclesiastics, some of whom had been compelled rather than induced by royal nuandate to speculate. Instead of solid fortunes were left heaps of bank bills, both counterfeit and good, which now were not worth a farthing. Everything was established on its old footing. The corporations and towns were more heavily engaged than before, but those hardest hit were probably the higher orders. The treasury returned to its old practices in order to reimburse itself; heavy sums were again forced from the reluctant cities. The royal inspectors went on their rounds and were paid for going, not by the government, but by the manufacturers, while heavy fines were imposed on those who sought to evade the law. That French 
industry survived the straitjacket which was put on to hinder every movement remains a wonder. But the narrowness of economic policy caused the professed aim to be defeated, just as in the days of Roman industrial régime. Some French industries still maintained their supremacy, especially whatever belonged to the realm of art and luxury. Porcelain and fayence were still in demand, and the factory at Sèvres began its famous career under the protection of Mme. de Pompadour. The mechanic improvements in spinning and weaving were imitated in France, and machinery was introduced, although the expense was considered extraordinary. Science and art again put themselves at the service of the crafts, for which the French have such peculiar aptitude. People had to be very industrious and inventive in order to keep away the misery which threatened such large portions of France. Commerce held the same position as industry. Objects of luxury easily found buyers abroad. As for ordinary merchandise, commerce in the eighteenth century was livelier than ever, in spite of the inferior quality of goods. Again a war interfered, the Seven Years' War, and made a reduction in foreign trade from 616 million livres to 322 while the war lasted; but when it was over commerce rose again rapidly to 725 million. In the administration of Fleury France enjoyed forty years of peace, during which commerce was trebled, but it is also necessary to say that it was almost ruined during the last war of Louis XIV. The following table may give an idea of the growth:

PROBABLE ANNUAL AVERAGE OF COMMERCE, I 7 I6-72.

(Numbers indicate millions of livres.)

\begin{tabular}{|c|c|c|c|c|c|}
\hline \multirow[b]{2}{*}{ PERIODS } & \multicolumn{2}{|c|}{ IMPORTATIONS } & \multicolumn{2}{|c|}{ EXPORTATIONS } & \multirow{2}{*}{ Total } \\
\hline & Europe & $\begin{array}{c}\text { Other } \\
\text { Countries }\end{array}$ & Europe & $\begin{array}{c}\text { Other } \\
\text { Countries }\end{array}$ & \\
\hline I $716-20 \ldots \ldots \ldots \ldots$ & 65.1 & 27.2 & I06.2 & I6.3 & $2 \mathrm{I} 4.8$ \\
\hline I $721-32 \ldots \ldots \ldots \ldots$ & 80.2 & 35.6 & I 16.7 & 31.7 & 264.2 \\
\hline I $7333-35 \ldots \ldots \ldots \ldots$ & 76.6 & 46.7 & $\mathrm{I} 24.4$ & 29.8 & 277.5 \\
\hline $1736-39 \ldots \ldots \ldots \ldots$ & 102.0 & 65.6 & 143.4 & 51.0 & 361.0 \\
\hline $1740-48 \ldots \ldots \ldots \ldots \ldots$ & II 2.8 & 69.8 & 192.3 & 46.2 & 430.1 \\
\hline I $749-55 \ldots \ldots \ldots \ldots \ldots$ & I 55.5 & 120.0 & 257.2 & 84.0 & 616.7 \\
\hline I $756-63 \ldots \ldots \ldots \ldots$ & I 33.7 & 40.9 & I 10.9 & 38.0 & 323.5 \\
\hline I7 $764-76 \ldots \ldots \ldots \ldots \ldots$ & 165.1 & 168.2 & 309.2 & 82.4 & 724.9 \\
\hline I $777-83 \ldots \ldots \ldots \ldots$ & 207.6 & I38. I & 259.8 & 78.0 & 683.5 \\
\hline I $784-88 \ldots$ & 301.7 & 266.0 & 354.4 & 139.5 & 1061.6 \\
\hline
\end{tabular}

The chief European countries with which France traded in 1787 were Italy, Switzerland, Genoa, Venice, Naples and Sardinia, Ger- 
many with Austria, Prussia and Poland, England and her possessions, the Hanseatic cities, Scandinavia, and Russia. With all these trade had increased since I716, while trade with Spain had remained stationary ; furthermore, Holland, the Ottoman empire, and Barbary, where French commerce held its own against the English. The reason why it is found difficult to give an accurate statistical estimate of commerce at this period is the peculiar organization of France into belts or zones for the collection of customs. An inner region comprised the five great farming districts surrounded by a line of posts for the levying of duties on export and import, but within which goods circulated more or less free of imposts. Another belt comprised half of southern France, Franche Comté, and Brittany, the so-calied reputed foreign provinces, where certain tariff systems, tolls, and duties flourished unabated; and a third belt comprised the former German provinces Lorraine, Alsace, and the three bishoprics, which might deal freely with foreign countries, but paid duty on export to the other French provinces. If to these be added five free ports situated outside the line of customs and dealing freely with foreign countries, it is easy to see that an attempt to estimate commerce from so many centers functioning separately and independently presents opportunity for statements of approximate rather than absolute truth. The wish to do away with this confusion and unite France within one boundary met with resistance on the part of the outlying provinces, which enjoyed a profitable trade and only desired free export into France as well. Favorable treaties with England and Russia, and the alliance with the United States, stimulated commerce considerably.

M. Levasseur next discusses the influence of the new ideas as represented by the economists. The demand for industrial liberty, total liberty, laisser faire, such as the contact with English political philosophy and the liberal ideas in America might bring forth, met with stern resistance on the part of those who thought the old, tried methods the best and were from nature or habit averse to change. The manufacturers themselves thought that the economists knew not what they were talking of, that they lacked practical experience, and clamored for more rather than less restriction. M. Levasseur reprints among the notes some of the reports, which are by no means unprofitable reading. Another interest just wakening was more concerned with improving the chances of the grain-growers. To make grain trade free, not only within the boundaries, but also 
with foreign countries, was the utmost the economists wished for. But the fear of making bread expensive made this object almost impossible, and even a series of good harvests could not persuade the poorer classes that export of grain would not eventually cause famine. The question of the grain trade alone, as one of the vital questions of the time, with the sidelight it throws on economic and political questions and prejudices, the nation's hopes and fears in a nutshell, as it were, might fill a whole book. Free trade in grain was not consistently attempted until the ministry of Turgot.

This remarkable man - remarkable for his keenness as a thinker, as an advocate of reform, and as an administrator - raised the question of the economic restoration or ruin of France into one of first magnitude, into something which the French people could never again lose sight of and which overshadowed every other. M. Levasseur reprints parts of the letter in which Turgot expressed his plea for the king's undivided support in case he was to create order out of chaos. The sad prophecy contained in this letter that the king would ultimately prove untrue to his own best interests has peculiar force to us, suggesting as it does the insignificance to which the king had sunk as compared with the coterie of greedy nobles; the absence of any progressive ideas among the courtiers, and the power which abuse had acquired over justice and even plain patriotism. Like Colbert, Turgot turned his attention to the finances, wherein seemed the root of the evil. In his own words, henceforth there must be "no bankruptcy, no increase of taxation, no loans." Labor must be assisted, not thwarted; freedom of commerce and of industry must set capital a-moving and leave scope for individual initiative; France must have her resources developed, her communications improved; arrears of taxes must be called, the privileged classes paying their share; the court must learn to husband its income. In the six edicts issued by Turgot which made such a startling impression on the friends of the old order, the corvée was abolished, at least as far as royal jurisdiction went; the offices for the supervision of ports, quays, and markets in Paris were abolished as well, corporations and fraternities were done away with, and the exercise of the trades made free to everyone who had conformed to the general police regulations. Other changes were effected by the edicts, but these are the most important. The preface to each set forth the legislators' ideas upon the matter, and was interded to win the people for the new measure by appealing to their sense of 
fairness and interest in their own well-being. The writer's eloquence, says M. Levasseur, was that of an honest mind. But the edicts nevertheless caused a storm of opposition, which never abated in strength until the king lost courage and let the reformer go. Marie Antoinette, who, at this time at least, had a mind for nothing but the satisfaction of her caprices, chafed at the necessary curtailing of expenses, and soon became the new minister's implacable enemy. Louis XVI., who wished to do the right thing, had neither foresight nor firmness to maintain the position once taken, but let himself be alternately bullied and persuaded till contempt rather than respect for his will or his opinion animated most of his advisors. It is strange that an outsider, like Marie Theresa, should regret the dismissal of Turgot more than did the persons most concerned. It is true Turgot was neither a Richelieu nor a Colbert; he had neither the tact nor the patience necessary to open a new era for France. But, however out of place the man, his ideas have been the seed of a new life for France, and while the monarchy refused his help, the Revolution made him its hero. If not a great minister, Turgot was a great man and a good citizen, a patriot of the best kind. A contemporary tersely remarked upon the news of his downfall: "It was an error to give such a position to such a man in a monarchy like ours." The sinister irony was but too true. No sooner was Turgot out of the game than the edicts announcing the liberation of the trades were annulled, the corporations were re-established, with some exceptions, as they had been before. New edicts followed reinstating the old methods. Reaction was in full force.

The taxes at the end of the ancient régime were briefly estimated by Necker to amount to 585 million livres. And yet during the war of the American Revolution it was necessary to borrow more than a milliard livres. In I789 the budget presented by Necker showed an income of 475 millions and an expenditure to the amount of 631.5 millions. The taxes from which this tremendous amount was to be defrayed were, of course, first the taille, paid by husbandmen and commoners. A nobleman might have a farm covering considerable plowland without having to pay a penny to the fisc; the great lord might extend his park and his forests without any dues to the treasury. Until the time of Louis XVI. the tax collectors had been responsible body and goods for the returns of the taille. Turgot did away with this solidarity which reminds one of the obligations of 
the Roman curiales. The collectors, however, did seldom proceed against the taxpayer according to conscience; the heaviest part of the burden was as a rule laid on those who had least means of redress. The only way to escape was to appear even more miserable than was really the case. The deceit practiced by the peasants is well known from contemporary literature. The poll tax was something everyone, whether common or noble, was expected to pay according to classification of property. But the clergy, the cities, and some of the provinces bought themselves free by a lump sum. The peculiar way in which classification was carried out is shown in Touraine, where the nobles paid 6,000 livres, the privileged classes 6,800 , the city population 45,000, while the peasants paid 290,000 livres. In I78I the income from the poll tax was 4I.5 millions (in Paris alone?). The twentieth which had superseded the old tenth was an emergency tax demanded from all subjects without exception. In 1756 (Seven Years' War) and later a second twentieth was asked for; and from 1760 to $I 762$ and $I 782$ to $I 786$ a third twentieth was repeatedly demanded. An edict exempted those whose income was less than 3 livres! The clergy usually bought itself free. For a long while the taxes were per annum and assessed individually. Necker did a notable kindness to taxpayers by decreeing that taxes once assessed remained the same for twenty years at a time. Necker in his "Adninistration of the Finances" informed the StatesGeneral that the roturiers, the common farmers, bore almost the whole of the taille, poll tax, and twentieth, the taille amounting to from 8 I to $9 \mathrm{I}$ million, the poll tax to 22 to 42 million, and the three twentieths from 74 to 76.5 million livres. Direct tax on industry brought little; the population of Paris was largely exempt from it; 2,046 letters of mastership granted in Paris brought the sum of 595, ooo livres. Other sources of income were the monopolies, the farming of certain grants not specified, which in 1786 were estimated to turn into the treasury the lump sum of 122.9 million livres or more. The administration of the domains Necker estimated at $\mathbf{5 2}$ millions. Other sources of income were the postal service which yielded the treasury 10.5 millions, and the lottery which gave II.5 millions after having consumed 44 millions in payment to winners. But with a newly acquired debt of a milliard and a half, even such sums as these wrung from the hard-working classes did not suffice. The court continued its drain on the finances, large sums being squandered in a night; and the whole fabric, so honeycombed with abuse, finally tottered to its ruin. 
The last chapter in the volume contains the detailed description of the general condition of the trades during this period. The aristocracy among the artisans were the jewelers, who had a coat of arms of their own, their own house, and the hierarchy of profession more firmly established than anywhere else. Only the masters had privileges, and among these again there were degrees based on the date when mastership was acquired and the dignities and offices held. Thus there were the young masters, the modern ones, the old masters, and the old wardens. The last were in the highest sense representatives of the guild, its traditions and aspirations, and tine jeaious guard it kept on its rights. With the jewelers the road to mastership was even longer and more tortuous than with the other guilds, and each master could not take more than one apprentice, who stayed with him for eight years and longer. The jewelers' guild, however, was even more renowned than the others for its magnificent charities, its distribution of food, care for the old and feeble among its own members, and for its alms. The sum of I0,000 to II,OOO livres was yearly spent in charity, I3,000 on the assemblies, elections, and offices. The six corps of merchants in Faris formed another kind of corporation, less well to do, but also less combative. They too had their coat of arms, and their members had the privilege of being aldermen and mayors of the capital. The other forty-four associations of trades created by the edict of I776 were reduced from eighty-eight older ones ; the right of mastership here cost Ioo to 800 livres, as compared with 600 to I,o0o livres in the six corps - sums which might be increased by the king in case of need. There were also certain parts of Paris where tradesmen were free to pursue their vocation without infringement on the part of the guilds. Here were situated the royal manufactories and other enterprises of private nature. In spite of jealousy on the part of the guilds, the king maintained the immunity of these parts, which comprised among others several streets, the neighborhood of some famous churches, the king's palaces, the houses of the princes of royal blood, and the suburb St. Antoine. The opinion of the corporations concerning the necessity of their own existence was not always the same. In their opposition to Turgot's reforms the masters spoke as if the welfare of the country depended on them. But later when the corporations were restored in I777 there were many who opined that monopoly helped only to maintain mediocrity. Corporations might be of use in large cities, but in smaller com- 
munities they seemed hurtful. Particularly the question of the mastership caused great difference of opinion, the suburbs of Paris wishing no restriction on the exercise of professions, other cities voting strongly for maintainig the old obligations unimpaired. The small industries were as important as ever. In I72I Paris had 757 bakers with a population of 500,000 (in I890, at a time when it was said bakers were too plentiful, there were I,522 with 2,447,957 inhabitants). In 1767 at Sens there were 2I grocers, II clothiers, 24 joiners, 25 shoemakers to supply 6,000 inhabitants (in I890, with a population almost twice as large, there were 14 grocers, I 2 haberdashers, 8 clothiers, 8 joiners, I 3 shoemakers). And in the country the small industries were even more important than in the city. At all times the peasants had woven and spun for their own needs. After the edict of 1762 they were free to work for the merchants in town or on their own account. In such provinces as Picardy the peasantry did a fair share of weaving, the manufacture of linen occupying no less than 24,000 looms. In the boroughs many masters were workmen as well, and often hired out to work for clients, who then furnished the material. In most shops, large or small, work was done by hand; certain industries, however, employed water or horse power. The spinning machines imported from England had begun to be used in many factories, but on the whole were still a novelty. The contest between machine work and man's hand began as early as Louis XIV., when the machine weaving of knitted goods was restricted to eighteen cities only in order that "bread be not taken away from too many people and the trade ruined by poor work."

Returning to the position of the individual workmen, M. Levasseur states that the condition of an apprentice was not particularly improved as the eighteenth century drew toward its close; in fact, there was a tendency to emphasize his dependence rather than otherwise. He was as before a maid of all work, the errand boy and obedient slavey of the household and the workmen. Entering when ten or eleven, he stayed under the master's tutelage three, five, or seven years, and the less he paid for his tuition the longer he had to stay. He ate in the kitchen and slept in the shop. Often peasants who wished their son to learn a trade paid in kind rather than in money, and sometimes they boarded him themselves. The apprentice was forbidden to stay away over night or leave the master before the time was up. The statutes knew no freedom for the 
workmen either. The distance between the orders was to be preserved. The workmen were forbidden to have tools of their own with which they might work for themselves and compete with their masters, and the masters were always taking pains that the workmen, even others than their own, should not get a job without their knowledge or consent. A workman could not leave with a piece of work unfinished; if he did, he was fined. The letter of leave, which he had to procure in order to be honorably dismissed, mentioned the amount of his indebtedness, if any, to the master he had just left; and the new master had to see to it that this debt was not left unpaid, but was deducted from his wages. Inasmuch as many workmen were poor and naturally improvident, most of them were in debt, and the master found the letter a good way of holding his employee responsible. No master could employ a workman unless his book of testimonials for good conduct and his certificate of payment of the registration fees were duly shown. No master must try to entice a workman to leave the shop of another to come to his own (which evidently was done quite frequently). The workmen, too, were prohibited from going abroad, and especially to foreign countries, where they were much in demand. Some were imprisoned and sent to the Bastille for no other reason. That this reactionary policy found severe critics among enlightened persons was but natural. Obligations ought to be mutual, they said, not only on one side; the workmen were not slaves. The wages, too, were considered too small, fixed solely with a view to the advantage of the employer. The many were sacrificed for the few. Accordingly mutinies and strikes were frequent. Apprentices were badly treated and so were the workmen, and cutting the work was probably considered the only way of getting "even" with the masters. In many shops as soon as a new workman entered work stopped at once and all hands resorted to the tavern. Any other chance of diversion was likewise eagerly sought - habits which seriously interfered with success and the outcome of which was loss. Strikes were of even greater importance. The strike of the silk workers at Lyons in $\mathrm{I} 744$ began as a protest against the regulations of the trade just issued; shops were destroyed, and for a while the strikers were in possession of the town, with the inevitable result of pillage. 'The reguiations were finally revoked, and amnesty was granted after some of the ringleaders had been sent to the galleys and one hung. The stronghold of such outbursts of discontent was the trade union, 
where help and encouragement were given the rebellious workman as well as the peaceful. The municipal police sometimes made raids on the "Mother," the tavern, where the companions assembled, seizing papers and money, when they found any. But, however undesirable from the point of view of peace and of unlimited authority of the privileged classes, the unions could not be abolished; they had to be ignored or tolerated. M. Levasseur reprints some documents showing the rules which governed some of these unions.

The wages paid the workmen at this period appear exceedingly low. If paid by the piece, and not by day as in large establishments, the conditions seem more tolerable. The list of wages, as presented in the large work of M. d'Avenel and reprinted here, may be of particular interest just now (p. 838). ${ }^{2}$ In regard to prices $M$. Levasseur points out that the breadstuffs rose in price constantly from the end of the Seven Years' War till the Revolution. Grain (wheat), of which the average price (I74I to I750) had been II.03 francs per hectoliter, after several bad harvests rose to 20 francs. Meat, butter, and eggs rose also. The price of bread in Paris was held down by the municipality which feared riots, and instead of I6 sous 4 denars, which should have been the price in 1789 , it was sold

${ }^{2}$ AVERAgE OF SALARY ESTIMATED IN FRANCS AND CENTIMES.

\begin{tabular}{|c|c|c|c|c|c|c|c|}
\hline \multirow{3}{*}{ Periods } & \multicolumn{4}{|c|}{ Agricultukal Day Laborers } & \multirow{3}{*}{$\begin{array}{l}\text { Masons } \\
\text { (per Day) } \\
\text { No Board }\end{array}$} & \multirow{3}{*}{$\begin{array}{l}\text { CARPEN- } \\
\text { TERS } \\
\text { (per Day) } \\
\text { No Board }\end{array}$} & \multirow{3}{*}{$\begin{array}{l}\text { Founders } \\
\text { AND } \\
\text { SmITHS } \\
\text { (per Day) }\end{array}$} \\
\hline & \multicolumn{2}{|c|}{ Male (per Day) } & \multicolumn{2}{|c|}{ Female (per Day) } & & & \\
\hline & Board & No Board & Board & No Board & & & \\
\hline 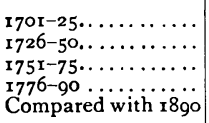 & $\begin{array}{l}0.35 \\
0.34 \\
0.37 \\
0.45 \\
1.50\end{array}$ & $\begin{array}{l}0.70 \\
0.68 \\
0.75 \\
0.82 \\
2.50\end{array}$ & $\begin{array}{l}0.20 \\
0.22 \\
0.22 \\
0.27 \\
0.90\end{array}$ & $\begin{array}{l}0.37 \\
0.45 \\
0.47 \\
0.50 \\
1.50\end{array}$ & $\begin{array}{l}0.98 \\
0.94 \\
0.90 \\
\text { I.15 } \\
3.40\end{array}$ & $\begin{array}{l}1.00 \\
0.96 \\
0.92 \\
1.20 \\
3.70\end{array}$ & 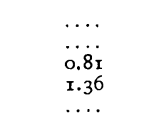 \\
\hline Periods & $\begin{array}{l}\text { TAILOR S, } \\
\text { WEAVERS } \\
\text { (per Day) } \\
\text { Board }\end{array}$ & $\begin{array}{c}\text { DRESS- } \\
\text { MAKERS, } \\
\text { MODISTES } \\
\text { (per Day) } \\
\text { Board }\end{array}$ & $\begin{array}{l}\text { Painters, } \\
\text { Plaster- } \\
\text { ERS } \\
\text { (per Day) } \\
\text { No Board }\end{array}$ & $\begin{array}{c}\text { BAKERS, } \\
\text { BuTCHERS } \\
\text { (per Mo.) } \\
\text { Board and } \\
\text { Lodging }\end{array}$ & \begin{tabular}{|c|} 
FARM \\
SERVANTS, \\
CARTERS, \\
SHEP- \\
HERDS \\
(per Year)
\end{tabular} & $\begin{array}{c}\text { Body } \\
\text { SERVANTS. } \\
\text { (Men) } \\
\text { (per Year) }\end{array}$ & $\begin{array}{c}\text { FARM AND } \\
\text { HousE SER- } \\
\text { vaNTS (Female) } \\
\text { (per Year) }\end{array}$ \\
\hline 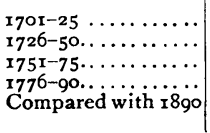 & $\begin{array}{l}\cdots \\
0.54 \\
0.62 \\
0.75 \\
\cdots\end{array}$ & $\begin{array}{l}0.26 \\
0.15 \\
0.30 \\
0.40 \\
\cdots\end{array}$ & $\begin{array}{l}1.04 \\
0.90 \\
1.12 \\
1.25 \\
3.50\end{array}$ & $\begin{array}{r}\ldots . \\
12.89 \\
9.50 \\
16.59 \\
\ldots\end{array}$ & $\begin{array}{r}71.00 \\
5500 \\
63.00 \\
80.00 \\
350.00\end{array}$ & $\begin{array}{r}55.00 \\
46.00 \\
50.00 \\
77.00 \\
369.00\end{array}$ & $\begin{array}{r}37.00 \\
30.00 \\
35.00 \\
42.00 \\
\text { Farm, } 214.00 \\
\text { House, } 300.00\end{array}$ \\
\hline
\end{tabular}


at I3, I2, and Io sous (October, I790). But even in the provinces bread was cheaper than would be supposed, probably because of the wheat being mixed with other nutritious grains. In I790 meat had a price corresponding to $0.65 \mathrm{fr}$. per kilogram for beef, veal, and mutton, and 0.79 fr. for pork. Milk was 0.27 fr. per liter in Paris and 0.15 fr. in the provinces; butter was I.28 fr. per kilogram, and eggs $2.80 \mathrm{fr}$. per hundred. It is difficult to indicate an average price for the greater number of manufactured goods. In I790 a pair of shoes cost 4 livres Io sous, and a pair of sabots 9 sous (rather cheap when compared with the average wages). The value of money, too, had sunk from I.22 fr. which the pound tournois was worth in I7OI to I725 to $0.90 \mathrm{fr}$. in I759 to I790. If the salary of the workingmen had risen 20 per cent. during the second half of the eighteenth century, the price of bread had risen 37 per cent., and hence the workman's wages were smaller while appearing higher. M. Levasseur tells us that an employer feeding four persons daily in I786) the workman not counted) needed eight pounds of bread, two pounds of meat, a bottle and a half of wine, besides vegetables, butter, and cheese. The artisan spent little enough on his person or on those who belonged to him. And how could he spend much, if the government was to have its due? In fact, as it was, expenses must in most cases have surpassed the income and a deficit been the natural result. The companion, or canute as he was called, lived even more modestly. His wages might amount to from 35 I to 374 livres per year, but, if he lived with his patron, the latter kept 240 livres for his board and other expenses. No wonder that the workman often had to ask for alms. The feelings of the underlings are forcibly expressed in their cahiers presented in 1789 to the Constituent Assembly. Here their demands were:

(I) that thenceforth wages be not so coolly calculated to satisfy the murderous maxims of luxury or insatiable cupidity; (2) that the preservation of the hard-working and useful man be a not less sacred object to the constitution than the property of the rich; (3) that a hard-working and useful man be not left uncertain of how he is to subsist within the extent of the empire.

Other voices were heard in behalf of the working classes; if these had been listened to instead of stifled by the reaction, France might have been spared the great upheaval which, as M. Léon Say says, cost so much blood and tears.

M. Levasseur closes the chapter with a discussion of the moral condition of the laboring classes. He assures us that good and bad 
elements were mixed here as elsewhere. Politeness, attractiveness of manner, respectful observance of the general prescripts of the church, and a certain neatness and elegance in appearance and dress seem to have characterized the working classes even then and struck foreigners as peculiar to the French. On the other side, drunkenness and perhaps not a high degree of honesty toward their employers were among the faults most complained of. The educational standard among the poorer layers of French society was not very high. Primary schools had been in existence since the sixteenth century, but parish schools became common only in the eighteenth. The four rules of arithmetic, the catechism, and the calendar were usually all that was taught. In the towns the Sisters of Charity kept girls' schools, and the Brethren of the Christian Doctrine had a thousand boys' schools. The registers of the corporations, which were kept by the masters themselves, show these capable of keeping accounts and wording the minutes; but the documents written by workmen give a much less favorable impression of the good they must have gotten from their instruction in school.

A. M. Wergeland.

UNIVERSITY OF WYOMING. 